\title{
Dil ve Politika İlişkisi Üzerine Bir Soruşturma: Dilin Politik Felsefeye Sağlayabilleceği İmkânlar
}

\section{An Inquiry into the Relation between Language and Politics: Possibilities Provided by Language to Politicial Philosophy}

\author{
Emine Canl1 ${ }^{1}$ (1)
}

'Dr., Istanbul, Türkiye

ORCID: E.C. 0000-0003-0012-6458

Sorumlu yazar/Corresponding author:

Emine Canlı,

İstanbul, Türkiye

E-posta/E-mail: eminecanli07@gmail.com

Başvuru/Submitted: 12.09 .2018 Revizyon Talebi/Revision Requested: 20.09.2018

Son Revizyon/Last Revision Received: 27.09.2018

Kabul/Accepted: 02.10 .2018

\section{Atıf/Citation:}

Canli, Emine. "Dil ve Politika İlişkisi Üzerine Bir Soruşturma: Dilin Politik Felsefeye Sağlayabileceği İmkânlar." Felsefe Arkivi 49 (2018): 23-36.

https://doi.org/10.26650/arcp2018-589785

\begin{abstract}
ÖZET
Bu çalışmada dil ile insanın politik düzlemdeki tasarlanışı arasında Antin Yunan'dan günümüze kadar doğrudan bir ilişki olduğu iddia edilecek ve bununla bağlantılı olarak politik düzlemin yeniden düzenlenmesinin de ancak dilin (yaratıcı olan) sunum (presentation) ve (düzenleyici olan) yeniden-sunum (representation) karakterinin açı̆̆a çıkarılmasıyla mümkün olduğu savunulacaktır. Bu amaçla, Platon'un Kratylos ve Aristoteles'in Politika metinlerinden yola çıkarak, ad (onoma), söz (logos), doğa (physis) ve yasa (nomos) arasındaki bağıntıları çözümleyeceğiz. Sonrasında ise Platon ve Aristoteles metinlerindeki dil ve politika ilişkisinin paradoksal yapısına Jacques Rancière "uyuşmazlık" (la mésentente, disagreement) kavramı ile işaret edilecek ve Walter Benjamin'in dil anlayışı üzerinden öneriler geliştirilecektir. Politik felsefe özelinde ilerleyecek çalışma bir bakıma, Platon'un dilin imkânının aynı zamanda felsefenin imkânı olduğu savı tersine çevrilerek politik felsefede yeni imkânların geliştirilmesinin de ancak dilin yeniden düşünülmesi ile mümkün olabileceğini göstermeye çalışacaktır.
\end{abstract}

Anahtar Kelimeler: Dil, politika, politik felsefe, sunum, yeniden-sunum

\section{ABSTRACT}

In this work, it will be argued that there is a direct relation between the ways language and humans have been projected in the political sphere spanning from Ancient Greece to our times. Accordingly, it will be asserted that a reorganisation of the sphere of politics is possible only by unearthing the creative (presentation) and regulatory (representation) character of language. In order to do so, we will analyse the ties between name (onoma), word (logos), nature (physis), and law (nomos) starting off with Plato's Kratylos and Aristotle's Politics. Later on, we will highlight the paradoxical structure of the relation between language and politics in the works of Plato and Aristotle using Jacques Rancière concept of disagreement (la mésentente) and develop certain propositions in this matter with the help of Walter Benjamin's understanding of language. This work, which in some respects, will progress focused on political philosophy, is an inquiry into the possibilities that a reconception of language may provide in developing new horizons in philosophy by reversing the assertions regarding the potential of language and philosophy of Plato.

Keywords: Language, politics, political philosophy, presentation, representation 
"Kekeleye kekeleye öldük. Perişan günlüklerimiz de
buna yeterince şahittir. İnsanın en üstün özelliğine,
açık seçik, canlı, açıklayan ve açıklarken teselli eden
sese sahip olamadık. Peki sesimiz olmuş olsaydı,
hayatı dile getirebilecek miydik? Bilmiyorduk ki."

Jules Michelet

Dil ve dilin politik düzlemdeki işlevinin açığa çıktığı nokta, felsefe tarihindeki diğer birçok problemin nasıl ilerleyeceğinin karara bağlandığı Platon ve Aristoteles metinleri uzamında karşımıza çıkar. Ve yine diğer birçok problemin yeniden düşünülmesinin imkânı gibi dilin politik işlevinin imkânı da Platon-Aristoteles metinleri uzamının oluşturduğu "Gordion düğümü”nden geçer. Bu sebeple, dil ve politikanın birbirine bağlandığı noktanın dilde politik olanın açığa çıkarılması ile çözümlenebileceğini düşünmekteyiz. Çalışmamızda, Platon'un Kratylos ve Aristoteles'in Politika metinlerinde dil ve politika bağıntısını saptamaya, Walter Benjamin'in dil düşüncesi ile dilin yeniden kurgulanışının imkânını sorgulamaya ve sonuçta, bakış açımızı tersine çevirerek, politikada dilsel olanın bir imkân yaratıp yaratamadığını sorgulamaya çalışacağız.

Kratylos diyaloğu Platon'un, hem dil sorunsalını hem de felsefe yapmanın ilkelerini belirlediği metindir. ${ }^{2}$ Platon için 'ad'ı (onoma), dolayısıyla onun ait olduğu daha genel bir yapı olan 'söz'ü ya da 'söylem'i (logos) doğru bir şekilde çözümlemek, filozofun kendi aletini tanıması anlamına gelir."3 Platon, ad ve söylemi doğa (physis) ve yasa (nomos) ile ilişkisi üzerinden çözümlemeye çalışır, fakat metnin sonunda söz konusu ilişkiyi bir açmaz (aporia) ile sonlandırarak sınırlar. Aristoteles ise açmazın eksenleri olan doğruluk (orthotês) ve hakikat (alêtheia) ile doğrudan ilgilenmez, ilişkiyi, cümleler (logoi) ve eylem üzerinden doğa (pyhsis) düzleminde çözümler. ${ }^{4}$

Platon açısından söylemin (logos) doğru bir şekilde kullanılabilmesinin yolu ad'ın (onoma) bilinmesinden geçer; bu nedenle Kratylos diyaloğunun merkezinde adın doğru bir şekilde saptanması vardır. Diyalogdaki ad tartışmasının bir tarafında, adın insanlar arasındaki bir uzlaşı sonucu ortaya çıkan sesler olduğunu savunan Hermogenes; diğer tarafında, şeyler ile adlar arasında doğal bir bağ, dolayısıyla doğruluk olduğunu ve ancak adların bilinmesi ile şeylerin de bilineceğini savunan Kratylos vardır. ${ }^{5}$ Sokrates ise hareket ifade eden adların yol açtığı yanılgılardan yola çıkarak, kendinde iyi ve güzel gibi değişime tâbi olmayanları (idealar, eidei) ileri sürerek bilginin imkânının ancak değişime tâbi olanlar ile olmayanların saptanması ile mümkün olacağını savunur. Bu da ancak iki tarafın savunularına karşı bir itiraz ve uzlaşı ile mümkündür, Platon düşüncesinin açığa çıktığı nokta da burasıdır. Platon'a göre şeylerin adları, herkesin katıldığı bir uzlaşı ile değil, işin ehli olan ad-koyucuların ad vermesi ile mümkündür; böylece Hermogenes

1 Michelet, Journal, haz. P. Viallaneix, Paris: Gallimard, 1959, c. I, s. 378, aktaran Jacques Rancière, Tarihin Adları: Bilgi Peotikası Alanında Bir Deneme, Çev. Cemal Yardımcı, İstanbul: Metis Yayınları, Şubat 2001, s. 94.

2 Erman Gören, Kratylos’a Yorumlar: Physis-Nomos Karşıtlı̆̆ı Bağlamında Filolojik ve Yorumbilgisel Bir İnceleme, c.2, İstanbul: Dergâh Yayınları, 2016, s. 11.

3 A.g.e. s. 11.

4 A.g.e., s. 52.

5 Platon, Kratylos: Giriş, Metin, Çeviri ve Dizinler, Çev. Erman Gören, İstanbul: Dergâh Yayınları, c. 1, 383a-384 
ile Kratylos'un savunduğu görüşler uzlaşmış olur ve fakat bu uzlaşı diyaloğun sonundaki açmazı (aphoria) doğurur.

Hermogenes'in ad ile şey arasındaki ilişkinin uzlaşı olduğunu ileri sürerken verdiği köle örneğinin metin içerisindeki konumlanışı ve Platon'un ad meselesini logos ve nomos düzlemine çekmesi ile daha sonra göreceğimiz üzere Aristoteles'in dile sahip insanı "politik bir hayvan" olarak tanımlaması ve politik düzlemi efendi-köle üzerinden kurması arasında tesadüfi değil, kararlı bir bağıntı vardır. Bu nedenle, dil ile politik olanın birbirine eşlik ettiği noktayı metinlerde kölenin konumlandırılışı üzerinden izlemek işlevsel olacaktır.

Hermogenes, adlar ile şeyler arasındaki doğruluğun insanlar arasındaki bir sözleşme ile açığa çıktığını düşünür ve evindeki kölenin adının kendinden menkul olmadığını, bir sözleşmede şey (pragma) olan kölenin ancak efendisi tarafından verilen ad ile evde ikâme edebileceğini söyler. ${ }^{6}$ Sokrates ise Hermogenes'in kölenin sahibine atfettiği ad verme hakkını, bireylerin mi yoksa kent devleti gibi ad verme konusunda bağlayıcılığı olabilecek ehil bir yapının mı sahip olması gerektiğine dair bir soruşturma için çıkış noktası olarak kabul eder.7 Sokrates bireyselliği (Protogoras’ın "her şeyin ölçüsünün insan olduğu” savına gönderme yaparak) bertaraf etmek amacıyla bir sözleşmenin önermeleri olan söz (veya söylem; logos) ile adı bir arada değerlendirir ve bütünü yanlış olan bir sözün parçasının da yanlış; bütünü doğru olanın ise parçasının da doğru olduğunu söyler. ${ }^{8}$ Hemen ilerisinde de söylem (logos), ad (onoma) ile doğa (physis) arasında bağıntı kurarak, bir şeyin doğası ile ediminin özdeş olduğu kabulünden yola çıkar ve doğru adın doğru edimi, yanlış adın ise yanlış edimi doğuracağını ifade eder. ${ }^{9}$ Böylece bir kölenin sözleşme gibi bir "söylem" de yer bulmasının imkânı ile adın (burada kölenin adı) uzlaşımsal mı doğal mı olacağı arasında ilgi kurulur.

Sokrates'in diyalogda mekik (kerkis) metaforu üzerinden ilerlettiği, bir adın doğruluğu yanlışlığı tartışması, esasında adın uzlaşımsal mı yoksa doğal mı kabul edilmesi gerektiğine dair bir tartışmadır. Sokrates'e göre bir edimin serimlenmesi her zaman kendisine eşlik eden ve kendisinin sabitlendiği bir ad ile mümkündür. Nasıl ki dokumak (edim) bir mekik (ad) ile mümkün ise bir edim olan söylem de adlarla mümkündür. Bununla bağlantılı olarak, bir şeyi en iyi dokuyanın herhangi biri değil beceri sahibi biri olması gibi, logos da ancak adı en iyi şekilde öğretecek bir ad/yasa-koyucu (nomothetês) ile mümkündür. ${ }^{10}$ Fakat Sokrates’e göre nasıl ki bir marangozun işi dümencinin nezaretinde dümen yapmak ise, ad/yasa-koyucunun işi olan ad koyma da ancak soru sormasını ve cevap vermesini bilen diyalektikçinin (başka bir deyişle filozofun) idaresi altında sürdürülebilir. ${ }^{11}$ Fakat Platon için diyalektikçi de tam anlamıyla yeterli olmaz; esasında mesele adın özü (ousia) ve sureti (eidos) ile ilgilidir ve "doğruluk (orthotês), bir şeyin niteliğinin ve suretinin tamamını kapsar." ${ }^{12}$

\footnotetext{
6 A.g.e., $383 \mathrm{~d}-\mathrm{e}$

7 A.g.e., 385a-b.

8 A.g.e., 385 c-386b.

9 A.g.e., $386 \mathrm{e} 5-387 \mathrm{~d} 8$.

10 A.g.e., $387 \mathrm{~d}-389 \mathrm{~b}$.

11 A.g.e., 390c2- 390d7.

12 A.g.e., $429 \mathrm{~d}-433 \mathrm{~d}$.
} 
Ad, her ne kadar söylem içinde bir şeyi ifşa (dêlôma) ediyorsa da ifşa edilenin doğru veya yanlış; iyi ya da kötü olması, şey ile ad arasında bir teamülü (ethos) gerekli kılar. Teamül, ifşa etmenin ötesinde hem ad ile şey arasında hem de farklı zihinler arasında bir tür sözleşmeyi (ksynthêknê) gerektirir. ${ }^{13}$ Teamül ve sözleşmenin koşulu kimsede değişime tâbi olmayacak iyi ve güzeldir; fakat ad'ın değişime tâbi olan doğası nedeniyle bu da mümkün olmadığı için, Platon'un sözleriyle, "dimağ/izan (nous) sahibi hiçbir insan kendisini adlara emanet etmez, kendi ruhunun bakımını onlara teslim etmez." ${ }^{14}$ Açmaz olarak kabul gören bu son esasında ad'ın ne olduğu ile ilgilidir; fakat adın söylem doğa ve yasa bağıntısında bir açmaz yoktur aksine yasa, adın güvencesi olur. Bir bakıma ad (onoma), söylem (logos) ve yasa (nomos) birbirlerine "karşılıklı koşul" ile bağlanmış gibidir. Başka bir ifade ile "bir yasa ona tâbi olanların uyması ve onun uygulanmasıyla gerçek anlamda yürürlüğe gireceği gibi, bir onoma da ancak logos içinde tayin edilen doğasına uygun şekilde kullanılmasıyla gerçek anlamda tedavülde sayılabilir." ${ }^{15}$ Dolayısıla bir adın iyiliği veya doğruluğu, "ancak ve ancak" söylemde ve yasada "sayılması", bir şeye işaret etmesi veya yürürlüğe girmesi ile mümkündür. Bu da temelde bir şeyin (pragma) meşruiyeti, onun adının ancak ad/yasa-koyucu tarafından konulmuş, söylemde veya yasada bir şeye işaret edebiliyor ve böylece kendisini yürürlüğe koyabiliyor olmasına bağlanmıştır diyebiliriz. ${ }^{16}$ Dil ve politikanın birbirine bağlandığı nokta da burasıdır, Platon dilin açmazının politik açmaz ile doğrudan ilgili olduğunun farkındadır ve açmaz ile kendisini politikanın felsefileşmesinden değil felsefenin politikleşmesinden korur. Çünkü politikanın felsefileşmesini Devlet’te filozof-kral önerisi ile çözülebileceğini düşünür, fakat felsefenin politikleşmesi Kratylos'ta gördüğümüz gibi kölenin konumu ile ilgili bir sorundur.

Aristoteles ise Politika'sının henüz girişinde, I. Kitap'ta, devletin nasıl doğal bir varlık olduğunu çözümlerken efendi ile köle olma durumunu da onların doğalarına dayanarak açıklar. Buna göre canlılar, doğada çift olarak vardır ve ancak çiftin bir araya gelmesi ile çoğalma gerçekleşir. Devlet gibi doğal bir amacın tezahürü olan yapıda da yöneten ile yönetilenin bir araya gelmesindeki ortak amaç, çoğalma gibi doğal bir ilke olan güvenliktir. Fakat bu ilişkide (Aristoteles'e göre yine doğal bir şekilde) "zekasıyla önceden görebilen bir kimse, doğaca yönetici ve efendidir; oysa beden gücüyle bunları yapabilen bir kimse doğaca köledir, yönetilenlerden biridir." ${ }^{17}$ Aristoteles'e göre kölenin doğası gereği köle olmasının nedeni, akıl yürütme yetisinden ona sahip olacak kadar değil, ancak anlayacak kadar pay almasıdır. ${ }^{18}$ Doğa, efendi ile köle arasında akıl yürütme yetisindeki bu "adaletsizliği" bedenlerinde dengeler; köleyi bedeni kol işlerinde güçlü

13 A.g.e., 343e6-435b.

14 A.g.e., 439c6- 440d.

15 Gören, A.g.e., 42.

16 A.g.e., s. 42.

17 Aristoteles, Politika, Çev. Mete Tuncay, İstanbul: Remzi Kitabevi, 1975, s. 7-8.

18 Jacques Rancière Aristoteles'in söz konusu köle tanımı ile Platon'un Menon diyaloğunda, Menon'un kölesine karakök kuramı buldurtarak aynı tanıtlamayı yaptığını söyler. fakat Rancière’in de belirttiği gibi kölenin problemi çözebilmesi, Sokrates ile aynı zekayı paylaşabilmesi, Platon için kölenin topluluğa dahil olmasının herhangi bir biçimini sağlamaz. Bkz. Jacques Rancière, Uyuşmazlık: Politika ve Felsefe, Çev. Hakkı Hünler, İzmir: Ara-lık Yayınları, 2005, s. 38. Ayrica bkz. Platon, “Menon”, Diyaloglar, İstanbul: Remzi Kitabevi, 1996, 82a-85c. Aristoteles, Politika, Çev. Mete Tuncay, İstanbul: Remzi Kitabevi, 1975 
yaratırken, özgür kişileri de kol işlerinde işe yaramayacak ancak bir devlet yurttaşı için uygun olacak şekilde dimdik yaratmıştır. ${ }^{19}$ Ve bir efendi (özgür kişi, yurttaş) köle edinmekle değil, onu kullanmakla efendi olur bu da ancak efendinin önce köleyi bir mülk gibi edinmesi (Kratylos'ta Hermogenes'in efendinin köleye ad vermesi gibi), sonra da onu yürürlüğe sokacak (işlev; ergon) bir söyleme (yasaya) tâbi kılması ile mümkündür. ${ }^{20}$ Bu nokta aynı zamanda Aristoteles'te devletin doğallığının gerekçesinin sağlandığı noktadır.

Devlet ve devletin birimleri olan efendi ve kölenin doğallığını ortaya koyduğunu iddia eden Aristoteles, devleti de varolan şeyler sınıfına ekler. İnsan ve insanların bir arada yaşadığı doğal yapı (devlet) ile doğadaki diğer canlı örgütlenmeleri arasındaki temel fark, insanın "politik bir hayvan" oluşudur. Bu nedenle Aristoteles'e göre tüm bu yapının düzleminde dil vardır. Dil, insan ve devlet arasındaki bağıntı olan politikanın temelidir; çünkü doğa, diğer canlılardan farklı olarak bir tek insana dili, anlamlı konuşma yetisini vermiştir ve bu sayede insan iyi ile kötüyü, adil olan ile olmayanı ayırt eder. Aristoteles'e göre bir devleti varlığa getiren, bu konularda (iyi-kötü veya adil olan-olmayan) ortak bir görüşün paylaşılmasıdır ve bu ancak özgür yurttaşların tâbi olacağı devletin veya filozofun rehberliğinde gerçekleşebilir. ${ }^{21}$ Böyle bir sistemde kölenin erdemi, efendisinin (özgür kişi, yurttaş) de bileşeni olduğu ortak görüş olan uzlaşıda (yasada) hizmette bulunmasıdır. ${ }^{22}$

Aristoteles'in, köle ile iş yapan (zanaatkâr) arasındaki ayrımı üzerinden düşündügüumüzde, sorunun antik ve modern karakteri birbirine yaklaşır. Aristoteles’e göre kölenin köleliği doğal olduğu için efendisinin yaşamı içerisinde kendisine yer bulurken; işçi işverenin yaşam dünyasında olmadığ 1 için işi ölçüsünde düzende yer veya erdem sahibi olabilir. ${ }^{23}$ Bu da yurttaşlığın ne olduğunun karara bağlanıp bağlanmaması ile ilgilidir. Aristoteles açısından doğal ve açık olan yurttaş tanımı, hem annesi hem babası yurttaş olan kişidir; fakat daha önceki kuşaklarında yurttaşlık arayan kişilerin çabalarını göz önünde bulundurduğunda vatandaşı doğal tanımdan sözleşmeye (yasaya) bağlanma gerekliliğini getirir. Buna göre yönetime (yasaya) katılan kişi yurttaştır. Fakat bu defa da karşı karşıya kalınan sorun, anayasanın değişmesi durumunda (anayasanın değişmesinin aynı zamanda bir devrim olduğunun farkındadır Aristoteles) yurttaşlığın ne olacağı, kimlerin yurttaş olabileceği, kölelerin ve yabancıların yurttaş olabilmesinin meşruiyetinin ne olacağıdır. ${ }^{24}$

Böyle bir tabloda karşımıza çıkan sorular ise şunlardır: dili kullanma (veya konuşma) kapasitesi eğer Platon'da iddia edildiği gibi şeylerden yola çıkarak gelişiyorsa, bir söylemde/yasada

19 Aristoteles, A.g.e., s. 14. Aristoteles, burada bazı akıl yetisi gelişkin insanların aynı zamanda bedenlerinin de kol işi yapacak kadar gelişkin olabileceğini (veya tersinin) ancak bunun doğanın nihai amacı içerisinde düşünüldüğünde bir istisna olduğunu söyler. Ona göre böyle istisnalar olmasaydı yani akıl yetisi gelişkin insanlar Tanrılar gibi kusursuz bir bedene sahip olsalardı zaten doğada efendiler ile köleler arasındaki ayrım zaten kabul görürdü. Dolayısıyla bu nokta ya Aristoteles'in doğayı nihai amacı üzerinden tanımladığını kabul ederek bir gelişim evresi olarak kabul edilecektir ya da köleliğin doğallığını kanıtlayamadığı düşünülecektir. Biz bu çalışmada dil üzerinden ikincisini savunacağı.

20 Aristoteles, A.g.e., 16-17.

21 A.g.e., s. $9-10$

22 A.g.e., s. 27-28.

23 A.g.e., s. 29.

24 A.g.e., s. 71-72. 
yer edinmek için köleler başta kendilerine sonra şeylere ad vermeye başlarsa ne olur? Aristoteles'te iddia edildiği gibi dili kullanma kapasiteleri dolayısıyla akıl yürütme kapasiteleri gelişkin insanlar (efendiler) köleler adına konuşursa ne olur ya da anayasanın değiştiği bir devrim durumu, zor kullanmadan değil de kölelerin dili kullanma/akıl yürütme kapasitelerinin gelişmesi sonucunda gerçekleşmişse meşruiyet sorunu çözülmüş olmaz mı?

Jacques Rancière de benzer kaygılarla kaleme aldığı Uyuşmazlık metninde politika ile felsefenin bir araya geldiği noktanın henüz başta Antik Yunan'daki logos kavramı ve problemi ile ilgili olduğunu savunur; çünkü logos, sadece basit bir konuşma değil, konuşmanın ürünü olan "sayım" ile ilgilidir. ${ }^{25}$ Bir toplumda adı sanı olmayan halkların (kölelerin) politik mücadeleleri varoluş mücadelesi ile doğrudan bağlıdır; çünkü mülkiyet ilişkilerinden önce esasında bir logos'a sahip olup olmadıkları görünüp görünmeyeceklerini belirler. ${ }^{26}$ Pierre-Simon Ballanche’’n 1829 'da “Tüm halkların tarihinin Roma halkının tarihine uygulanmış genel formülü” adı altında yürüttüğü makalelere başvuran Rancière, çalışmasında, Ballanche’ın daha önce tarihi bir mesele olarak ele aldığı Roma pleblerinin Aventinus Tepesi'ne çekilmelerini anlatısını merkeze alır. Rancière, Ballanche'ın patrisyenlerin ve pleblerin herhangi bir meseleyi tartışabilecekleri ortak bir sahnenin var olup olmadığını ortaya çıkarma çabası ile logos arasında ilgi kurar. Rancière’e göre plebler, partisyenler ile aynı sahnede bulunamazlar çünkü konuşamazlar ve ("şehir içince tutulan sembolik kayıttan yoksun olma anlamında”) logos'tan yoksun, adı sanı olmayan varlıklar olup (tam da Aristotelesçi anlamda) yaşamları üreme işlevine indirgenmiştir. ${ }^{27}$ Konuşma ve akıl ürütme yetisine sahip olmadığı kabul edilen pleblerin sözlerinin partisyenler tarafından nasıl algılandığını Ballanche şöyle anlatır:

Onlar tıpkı bizim gibi konuştular, Menenius'a lâf anlatmaya cüret ettiler! Menenius'un ağzını kapatan, gözlerini kamaştıran, kulaklarını çınlatan bir tanıı mıddı?... Yalnızca gelip geçici bir konuşma yaptıkları, bir zekâ ifadesi değil de uçup giden bir ses, bir tür bögürme, bir ihtiyaç alâmeti olan bir konuşma yaptıkları tanıtını nasıl oldu da vermedi. Onlar öncesiz-sonrasız sözden yoksundular, bu geçmişte böyleydi ve gelecekte de böyle olacak. ${ }^{28}$

Avenitus'ta toplanan köleler, daha önceki kölelerden farklı olarak öteki savaşçılarla eşit savaşçılar olduklarını (Aristotelesçi anlamda; bir köle için zaten doğal olan beden güçleri üzerinden) savunmazlar aksine onları logos’un düzeninden men edenler (yine Aristotelesçi anlamda dili kullanma/akıl yürütme yetisine sahip olanlar) ile aynı özellikleri gösterirler ve kendilerini konuşan varlıklar olarak tasarlayacak yeni bir düzen kurarlar. Patrisyenler gibi lanetlemelerde ve övgülerde bulunurlar, kendi kahinlerine danışmak için delegeler ve kendilerini

25 Fakat Rancière'in logos'un ikili yapısı dediği sanma ve sayılma esasında birimi olan onoma'nın yapısından kaynaklanır. Bunun ne gibi bir fark yaratabileceğine, ileride Benjamin’in dil düşüncesine geldiğimizde değineceğiz. Onoma’nın söz konusu ikili yapısı için bkz. Gören, Kratylos’a Yorumlar, s. 42.

26 Rancière, A.g.e., s. 44.

27 A.g.e., s. 45.

28 Pierre-Simon Ballanche, "Formule générale de l'histoire de tous les peuples appliquéeà histoire de peuple romain", Reveu de Paris, Semptember, 1829 s. 94 . Aktaran Rancière, A.g.e., s. 46. 
temsil etmeleri için ise temsilciler seçerler. Pleblerin bu atılımı Ballanche’ın ifadesiyle "göğe bir ad yazma”, Rancière'in ifadesiyle ise Roma şehrinde kendilerine yer açmaktır. ${ }^{29}$

Rancière, bu noktada söz konusu logos'un yeniden düzenlenişinin imkânını (bize göre Aristotelesçi politikaya karşı bir sav olarak) politika ile polis (police)' in "uyuşmazlık" noktalarının çözümlenmesine ve daha önce sayılmayanların sayılma pratiklerine bağlar. Kendi ifadesi ile:

\begin{abstract}
Ortaklaşalıkların kümelenmesinin ve rızasının işler kılınmasını, güçlerin örgütlenmesinin, yerlerin ve işlevlerin dağıtımının ve dağıtımı meşrulaştırma sistemlerinin gerçekleştirilmesini sağlayan prosedürler kümesine genellikle politika adı verilir. Bense, bu dağıtıma ve meşrulaştırma sistemine başka bir ad vermeyi öneriyorum. Onu polis (police) diye adlandırmayı öneriyorum. ${ }^{30}$
\end{abstract}

Polis, logos'un yani görünür ve söylenir olanın düzeni iken; onun karşısında konumlanan politika ise polis'in düzeninden hiçbir pay alamayanları ön varsayım olarak kabul eder ve daha önce uğutlu olarak işitilen şeyi söylem olarak anlaşılır kılar. ${ }^{31}$ Fakat Rancière, tam bu noktada, politika’nın mantığının kökeni itibariyle polis'in mantığından ayrılsa da esasında bağlantılı olduğunu söyler. Çünkü politikanın kendisine özgü bir nesnesi ve konusu yoktur, bu nedenle politika her zaman polis üzerinde eyler ve polis' in yadsınışından başka bir şey değildir. ${ }^{32}$ Politikanın polis'teki “özneleşme” tarzlarıyla ilgili olduğunu kabul eden Rancière, söz konusu özneleşmenin, polis' in "yeniden şekillendirilmesinin bir parçası olan bir bedenin ve söz-söyleme yeterliliğinin bir dizi eylem aracılığıyla üretimi” olduğunu söyler. ${ }^{33}$

Biz ise Rancière'in politika ile polis'in mantığının özdeşliğini ileri sürmesinin nedeninin özneleşme sürecini logos ile sınırlaması olduğunu düşünmekteyiz. Çünkü logos'u ortaya çıkaran ad ve adın yürürlüğe geçtiği, karara bağlandığı yasaya değinilmediği sürece politika her zaman polisìn üzerine kapanacaktır. Bu nedenle problem, Antik Yunan'daki çıkış noktası olan dil ile politik olanın kesiştiği noktaya, o noktanın inşa edildiği kavramlar ile yeniden çekilmelidir. Çünkü dilin kurgulandığı kavramların birbirleriyle bağlantılandırılma tarzlarına dair eleştiri geliştirilmediği sürece, dilin ürettiği söylem (logos) üzerinden geliştirilecek özneleşme çabalarının polis'in düzenine eklemlenmesi ve varoluş mücadelesinin son kertede söylemdeki bir anlatıya dönüşmesi kaçınılmazdır. Nitekim Rancière’in de "uyuşmazlığın akılsallığı" dediği; politikanın, logos'un ikili yapısı (konuşma ve sayma) nedeniyle kendisini akıl-dışılıktan ayırma mantığının kaçınamadığı nokta da budur. ${ }^{34}$

Bu noktada, biz, dil ile ilgili ileri süreceğimiz savlardan yola çıkarak, politikanın mantığının nesneleri ve ilkeleri nedeniyle zorunlu olarak polis’in mantığına bağlı olmadığını düşünüyoruz. Çıkış noktamız ise nesneler arasındaki ilişkinin dış dünyada, ampirik düzlemde değil dilde

29 Rancière, A.g.e., 46-47.

30 A.g.e., 50-51.

31 A.g.e., 52-53.

32 A.g.e., 55-56, 58.

33 A.g.e., 59-60.

34 A.g.e., 71. 
kurulduğu savıdır. Bu, Rancière’in ileri sürdüğü gibi politik nesnenin ampirik düzlem olan polis'in nesnesi ile özdeş olmadığı anlamına gelir. Benzer şekilde politik ilkeler de (eşitlik gibi) polis'teki nesneler arasındaki ilişkide değil o nesnelerin dildeki temsillerinde kurulur. Nitekim, nesneler arasındaki ilişkinin dış dünyada kurulduğunu düşünmek dili de politikayı da kaçınılmaz olarak uzlaşımsal tasarlamakla sonlanır. Platon ve Aristoteles'teki ad (onoma), söylem (logos), yasa (nomos) ilişkisi ile Rancière’in bu ilişkiyi çözme çabasının yine polis'in mantığına yerleşerek uzlaşmaya işaret etmesinin nedeninin de bu bakış açısı olduğunu düşünüyoruz.

Dil ile ilgili savlarımızın teorik arka planını Yalçın Koç’un, "Mekân ve Nesne” makalesine dayandıracağız. Koç, bir nesnenin mahiyetinin sadece kendisinden yola çıkarak anlaşılamayacağını ve nesnenin, ait olduğu mekânın (temel, dayanak) şartları ve imkânlarına tâbi olarak meydana geldiğini, dolayısıyla nesnenin ne olduğunun, mekânının mahiyetinin ne olduğu sorusu ile iç içe ilerlediğini söyler. Mekân, dış dünyadaki bir zemin, yüzey değildir; çünkü "doğal sayı" gibi bir matematik nesne veya "Roma İmparatorluğu" gibi tarihsel bir nesne ile bir yüzeyde karşılaşmayız. ${ }^{35}$ Koç'a göre;

Bir nesnenin tâbi olduğu şartlar, bu nesnenin mekânının imkânları ile ilgilidir. Bir mekânda bulunan nesneler arasındaki ilişkiler de bu mekânın imkânlarına bağlıdır. Meselâ, bir nesnenin "sebep-sonuç" ilişkisine tâbi olup olmadığı, bu nesnenin mekânının imkânları ile belirlenir. ${ }^{36}$

Fizik nesneler, mekânları sebebiyle zamana ve sebep-sonuç ilişkisine tâbi iken; matematik nesneler, zamana ve dolayısıyla sebep-sonuç ilişkisine tâbi değildirler. Burada karşımıza, matematik nesneler ile fizik nesneler gibi, farklı mekânlardaki nesneler arasındaki ilişkinin nasıl kurulduğu sorusu çıkar. Koç, farklı mekândaki nesnelerin ancak temsilleri aracılığıyla dilde ve düşüncede birbirlerine "dokunma" imkânına sahip olduğunu ve bu haliyle de artık söz konusu olanın matematiksel ve fiziksel nesnelerin kendileri değil, "temsilleri” olarak düşünsel ve dilsel nesneler olduklarını söyler. ${ }^{37}$ Dolayısıyla dil, sadece "nesnelerin temsillerinin birbirlerine 'dokunmalarına' imkân tanıyan bir 'kab' olarak ortaya çıkar." Örneğin "Aile, aynanın bulunduğu odada bir araya geldi” önermesinde; "aile” sözcüğü ile temsil edilen şey, sosyolojik bir nesneyi; "ayna” ve "oda" sözcükleri ise fiziksel nesneleri temsil eder. Bu önermedeki nesneler farklı mekânlardaki nesnelerdir ve ancak dilde temsilleri aracılığıyla birbirlerine "dokunurlar." 38

Koç, esasında Turing makinesi testi ile birlikte artık fiziki nesnelerden matematiksel nesnelere doğru sıçrama yapılabileceği savunularına karşı yazdığı metinde ulaştığı sonuçlarla yapay zeka tartışmaları arasında ilgi kurar. Koç’a göre Turing makinesi hem hala bir makine olarak fiziki bir nesne olduğu (kavram oluşturamaması ve muhakemede bulunamaması nedeniyle) hem de dilin birer "temsil" olan nesnelerin farklı mekanlardaki nesneler arasında varlıksal bir "geçişe" veya "bütünleşmeye” imkân sağlayamaması nedeniyle mevcut girişimler başarılı olamaz. Biz ise Koç’un

35 Yalçın Koç, "Mekân ve Nesne”, Felsefe Arkivi, İstanbul: Edebiyat Fakültesi Basımevi, Sayı:29, 1994, s. 13-14.

36 Koç, A.g.e., s. 15.

37 A.g.e., s. 15-16.

38 A.g.e., s. 18-19. 
nesne ve dile dair tespitlerinden yola çıkarak dil ile politik olan arasında ilgi kurmaya çalışacağız. Ad'ı nesnelerin dildeki temsilleri ${ }^{39}$; logos'u ampirik düzlemde birbirlerine dokunamayan nesnelerin dokunma düzlemi olarak ele alacağız ve bunun karşısında nomos'u da Turing makinesi gibi otonom, söylem (logos) vaz’ edebilecek bir “yapı” olamayacağını söyleyeceğiz.

Anlattığımız üzere, Platon ve Aristoteles metinleri uzamı bize adın, ya doğal ya da uzlaşımsal olarak düşünebileceğini söyler; fakat bugün hala, adın kendinde ne olduğu veya ad-verme eyleminin ilk nasıl gerçekleştiğine dair nihai bir açıklama geliştirilebilmiş değildir. Kratylos'un açmaz ile bitmesi aslında diyaloğun çıkış noktası olan adın doğal mı uzlaşımsal mı olduğu meselesinin "teorik anlamda" bir paradoks oluşturmasındandır. Fakat bizce her ne kadar Platon ve Aristoteles'in doğallığ $1 \mathrm{~m}$ uzlaşımsallığ $1 \mathrm{~m}$ s savundukları hala tartışılsa da ikisi de söz konusu tartışmanın paradoks oluşturduğunun farkındadır ve ad meselesini yasa ve doğaya bağlamaları da buradan kaynaklanır. Adı, doğa ve yasa düzleminde değerlendirmeleri hem herkesin ad-koyucu olmasını engeller hem de söylemin öznesi olan insan, doğanın nesnesi olduğu için insanın söylemini, yapının (doğa veya yasa) düzenlenişi üzerinden kontrol edilebilir bir şekilde tasarlamalarını sağlar. Doğanın doğallığının karşısında; söylemler bütünü olan nomos'un yapı olarak tesis edilebilirliğinin önemi de burada açığa çıkar. Nomos, (Turing makinesi gibi) farklı mekanlardaki nesneler arasında geçişe ve bütünleşmeye olanak sağlamakla birlikte "tekilliğini” de iddia edecek şekilde otonom bir yapı şeklinde kabul görür. Nomos ya Platon düşüncesinde olduğu gibi iyi ve güzel idealarına veya hakikate; ya da Aristoteles'te olduğu gibi doğal bir yapı olan devlete bağlanır. Böylece pek tabii ki efendi, efendi olarak; köle de köle olarak kalacaktır. Bize göre ise adın kendinde ne olduğundan ziyade kapasitesi göz önünde bulundurularak düşünülmesi, onun logos ile ilişkisinin yeniden tasarlanışını da etkileyebilir. Bu noktada ise Walter Benjamin'in dil ile ilgili metinlerinden yararlanacağız.

Benjamin'in dil düşüncesi, daha baştan "ad" ve "söz" arasında düzlemsel ayrım yaparak paradoks da dediğimiz Gordion dügüumünü kılıçla kestiği için önemlidir; çünkü Benjamin, dügümün bir çözümünün olmadığının farkındadır. Her ne kadar Gordion dügüumü anlatısında olduğu gibi felsefi bir yaklaşım olarak da düğümün kılıçla kesilmesi "barbarca" karşılansa da ${ }^{40}$ bize göre Benjamin’in dil düşüncesi doğalcılık ve uzlaşımsalcılık ekseninde düğümü çözme girişimlerinin her defasında nomos ile bir uzlaşıyı talep ettiğinin farkındadır.

Politik felsefenin imkânı, Platon'un Kratylos diyaloğunda saptadığı gibi hem felsefenin hem de politik olanın imkânı olan dil'dir; çünkü dil hem bir şeyi sunma (presentation) hem de temsil etmenin (representation) düzlemidir. Dolayısıyla dili nasıl tasarladığımız, insanı ve insanın doğa ve politik olan ile kurduğu ilişkiyi nasıl tasarladığımız ile doğrudan ilgilidir. Benjamin

39 Burada “ad'ı nesnelerin dildeki temsilleri” olarak ele alırken Platoncu anlamda ad'dan söz ediyoruz, ilerleyen aşamada Benjamin bahsinde ad ile söz arasında ayrım koyarak, adın, sunum; sözün ise yeniden-sunumun bir bileşeni olarak değerlendireceğiz.

40 Jean-Paul Sartre, Varlık ve Hiçlik: Fenomenolojik Ontoloji Denemesi, Çev. Turhan Ilgaz, Gaye Çankaya Eksen, İstanbul: İthaki Yayınları, 2009 s. 334. Aristoteles'in Politika'daki barbar ile ilgili düşünceleri de logos’u yeterince kullanmamakla ilgilidir. Düğümün çözümü (efendinin niteliği olan) söz ve düşünme yetisi ile sağlanırsa Hellence; kılıç ile (köledeki beden gücü gibi) barbarcadır. 
düşüncesinde de bu anlamda dil, prima philosophia'dır. ${ }^{41}$ Benjamin'in dil çalışmalarından yola çıarak dilin yaratıcı karakterini sunum (presentation); düzenleyici karakterini ise yeniden-sunum (re-presentation) olarak ele alacağız. Dilin yaratıcı karakterini sunum şeklinde değerlendirmemizi "Genel Olarak Dil ve İnsan Dili Üzerine" metnine; düzenleyici karakterini yeniden-sunum şeklinde değerlendirmemizi ise The Origin of German Tragic Drama metninin giriş bölümü olan "Epistemo-Critical Prologue”a dayandıracağız.

Benjamin'e göre felsefenin karşı karşıya olduğu temel soru, yeniden-sunum (representation)'dur; çünkü bir problemi temsil etme tarzımız o problemi düşünme tarzımız ile ilgili olmakla birlikte felsefe yapma tarzımızı da doğrudan belirler. Yeniden-sunum, geleneksel felsefi yaklaşımda olduğu gibi “yapı” olma amacı üzerinden düşünüldüğünde “örümcek ağı” gibi gerçekliği kendi ağına çekerek içeriği forma göre düzenler ve aynılaştırmaya çalışır; fakat "doktrin" olarak düşünüldüğünde fenomenin özgünlüğünü korumaya çalışır. Yeniden-sunumun ilk karakteri bilgiyi (knowledge); ikinci karakteri ise hakikati (truth) refere eder ve bilginin nesnesine sahip olmaya çalışan metoduna karşı hakikat, nesnelerin kendinde-temsilinde (self-representation) içkindir; başka bir ifade ile fenomenlerde öz (essence) olarak mevcuttur ve açığa çıkarılmayı bekler. ${ }^{42}$

Benjamin’in saptadığı bu nokta yeni bir felsefe yapma tarzıdır; çünkü yeniden-sunum ile Benjamin, felsefeye metodik bir revizyon önermemekte, aksine, sürdürülmekte olan metottan vazgeçmeyi hedeflemektedir. Fakat çokça düşünüldügü gibi Benjamin’in hakikati refere eden yeniden-sunum düşüncesi, epistemolojik iddiadan vazgeçmez, geleneksel epistemolojinin "politikeleştirel”^3 bir okumasıdır. Dolayısıyla Benjamin düşüncesine dair yapılan çalışmalardaki yaygın kanının ileri sürdüğü gibi burada epistemolojinin karşısına epistemolojik olmayan savunusu yapılmaz; aksine fenomenlere dair epistemolojinin sadece geleneksel felsefenin vaz’ ettiği şekilde yapılamayacağı ileri sürülür. ${ }^{44} \mathrm{Bu}$ noktada Benjamin metinlerinde iz sürdüğümüzde politikeleştirel okumanın hedeflediği yeni felsefe yapma tarzının yeniden-sunum ile bağlantısının açığa çıkarılması gerekmektedir. Karşımızdaki soru ise şudur: Sunum nedir ki yeniden-sunum yeni bir felsefe yapma tarzına imkân sağlayabilmektedir?

Benjamin düşüncesinde yeniden-sunum "takımyıldız" da dediği "fikirler teorisi”ne dayanır. Takımyıldız teorisinde fikirler, nesnelerin salt kavramları ve yasaları olmadığı gibi onların bilgisini de genişletmez; çünkü fikirler nesnelerin temsilleri olan kavramlarda somut unsurların düzenlenmiş halinin yeniden-sunuluşudur. ${ }^{45}$ Başka bir ifade ile kavramların "takım" oluşturmuş hali, nesnelerin temsilleri olan kavramların fikirler olarak düzenlenmiş yeniden-sunumudur ( $r$ -

41 Peter Osborne, Charles Matthew, "Walter Benjamin” (Çevrimiçi) https://plato.stanford.edu/entries/benjamin/

42 Walter Benjamin, The Origin of German Tragic Drama, trans. by John Osborne, London: Verso, 2003, s. 27-30. (Bu noktanın, Platon düşüncesinden farkı, ileride ad ve söz bahsinde açığa çıkacaktır.)

43 Kia Lindroos, Now-time Image-space: Temporalization of Politics in Walter Benjamin's Philosophy of History and Art, Finland, SoPhi AcÂdemic Press, 1998, s. 20.

44 Bkz. Emine Canlı, "Politik Praksis İmkanı Olarak Walter Benjamin'in Tarih Kavramı Üzerine Bir İnceleme”, İstanbul Üniversitesi Sosyal Bilimler Enstitüsü, İstanbul, 2018, Yayınlanmamış Doktora Tezi, s. 108-109.

45 Benjamin, The Origin of German Tragic Drama, s. 34. 
presentation). Benjamin'in ifadesi ile: “Takımyıldızlar yıldızlar için ne ise, fikirler de nesnelere göre odur." ${ }^{46}$ Nasıl ki takımyıldız yorumlanmış grup halindeki yıldızlar ise, fikirler de nesnelerinin temsillerinin gruplanmış nesnel yorumlarıdır. ${ }^{47} \mathrm{Bu}$ görüşte fikirler, kavramsal olanı yadsımaz aksine kavramları kullanmanın farklı yoludur. ${ }^{48}$

Takımyıldız teorisinin nesnel yorumlama çabası, geleneksel nesnellik kavrayışına eklemlenmez ve geleneksel nesnelliğin ampirik gerçekliği kavramsallaştıran dil anlayışını araçsal bularak onun kökenine eleştiri yöneltir. Benjamin'e göre hakikat, ampirik gerçekliği kavramaktan ziyade onun özü ile ilgilenir ve tam da bu nedenle varlığın fenomenal özü olan "ad”a (onoma, der Name) yönelir. Benjamin'e göre Platon'un idealar kuramında kavramlara kutsallık atfedilmesi de bu nedenledir. Çünkü idea esasında dilseldir; bir sözün (word) özüdür. ${ }^{49}$ Platon'da felsefecinin görevi yeniden-sunum faaliyeti ile sözün özünde yatanı ( $\left.\mathrm{dd}^{\prime}{ }_{1}\right)$ ona geri vermek olarak saptanır. ${ }^{50} \mathrm{Bu}$ noktada, Benjamin düşüncesinde dilde sunulanın ad; yeniden-sunulanın ise adlar arasındaki bağıntılar olan fikirler olarak kabul edildiğini görürüz.

Benjamin'e göre, Platoncu anamnesis (yeniden-hatırlama) kavramı, yeniden-sunuma yakın gibi görünse de esasında farklıdır. Çünkü idealar kuramında idealar, kendilerinde uzam ve zamana tâbi olmayanlar olarak ad verme gibi düşünüldüğünde dahi şeylerin "ad verme hakkı"nın adın kendisinden menkul olduğu düşünülmez. Benjamin düşüncesinde bu tutumu sergileyen ise Âdem'dir. Âdem, dil ile şeylere ad vermeyi imlediği için insanlığın ve felsefesin babasıdır. ${ }^{51}$ Platon'da anamnesis yanıltıcı olandan hareketle hakiki olana doğru bir hatırlama faaliyeti iken; Âdem, şeyleri adlandırırken, onlarla bir dünya elde eder. ${ }^{52}$ Bunun yanı sıra, Âdem'in ancak cennetten yeryüzüne intikalinden sonra şeyleri adlandırması cennetin, kelimeler aracılığıyla iletişim kurmak gibi bir zorluğun çekilmediği yer olduğunu ${ }^{53}$ göstermekle birlikte dünyanın da ad-verme faaliyeti ile yeniden-kurulan bir yer olarak düşünülmesine imkân sağlar. Bu kurucu faaliyet, Benjamin'in ifadesi ile yeniden-sunum faaliyeti fikirler ile gerçekleşir: “Âdem'in doğayı adlandırdığı gibi, felsefe de adlandırmak için fikri kullanır.”54

Benjamin'in ad ve dil meselesini merkeze aldığı metni ise "Genel Olarak Dil ve İnsan Dili Üzerine” dir. Metindeki dilsel öz ve tinsel öz ayrımı, esasında adın doğal mı uzlaşımsal mı olduğu tartışmasının tezahürüdür. Benjamin'in dilsel ve tinsel öz ayrımı paradoksu çözmeyi amaçlamaz, aksine, ad'a dair bu tartışmanın tam da neden bir paradoks oluşturduğunu serimlemeye çalışarak

46 A.g.e., s. 34.

47 A.g.e., s. 34.

48 Fred Rush, "Sunuş", Walter Benjamin Alman Romantizminde Sanat Eleştirisi Kavramı, Çev. Elçin Gen, İstanbul: İletişim Yayınları, 2013, s. 50.

49 Benjamin, The Origin of German Tragic Drama, s. 36.

50 A.g.e., s. 36.

51 A.g.e., s. 36-37.

52 Rush, A.g.e., s. 43.

53 Benjamin, The Origin of German Tragic Drama, s. 37.

54 Walter Benjamin, The Correspondence of Walter Benjamin: 1910-1940, edited and annotated by Gerschom Scholem and Theodor Adorno, translated by Manfred R. Jacobson and Evelyn Jacobson, London, The University of Chicago Press, 1994, s. 234. 
derinleştirir. Ad ve dil tartışmasını dilsel öz ve tinsel öz ayrımı üzerinden ilerleten Benjamin, ikisinin birbirinden ayırt edilememesinin nedeninin sıkça logos'un çift anlamlılı̆̆ına atfedildiğini ve son kertede iki anlamının özdeşliğinin kabul edildiğini, bu sebeple sorunun paradoksal ve çözümsüz kaldığını söyler. ${ }^{55}$ Tinsel özü ad'a atfeden Benjamin, tinsel özün kendisini dilsel özün içinde ilettiğini söyler ve ekler; insanın dilsel özü bizatihi kendisinin dilidir. Başka bir ifade ile insan, kendi tinsel özünü dilinde iletir bu da insanın diğer tüm nesneleri adlandırmasından kaynaklanır. Varolanlar arasında sadece insan dili adlandırır; fakat insanın nesneleri adlandırması tinsel özü iken sözde dile getirmesi onun dilsel özüdür. ${ }^{56}$

Benjamin ad ile "kendi başına dil"in (herhangi bir dilin değil, genel olarak dil'in) insanın tinsel özü olduğunu güvenceye alır; çünkü ad, dilin dilidir. Kendinde dil'in uzamında olan insanın adlandırma kapasitesi nedeniyle, Tanrı'nın yaratısı ancak nesnelerin insan tarafından adlandırılmasıyla tamamlanır. ${ }^{57}$ Fakat yaratım faaliyeti olan adlandırma insanın tinsel özü olarak "kendi başına dil” in güvencesidir; insan, nesnelerin diline ise söz aracılığıyla bağlanır. Ad ile söz arasında derece farkı koyan Benjamin'e göre, adın doğal mı uzlaşımsal mı olduğu tartışmasının paradoksa dönüşmesinin nedeni ad ile söz arasındaki derece farkının anlaşılamamasıdır. Oysa “insanın sözü, nesnenin adıdır." Nesnenin insan sözünde dile getirilmesinin yaratım anlamında bir adlandırma olduğunu düşünmek (doğalcı yaklaşım), esasında sözü nesnenin özü sanmaktan kaynaklanır. Oysa nesnenin kendinde sözü yoktur; çünkü o Tanrı’nın kelamından yaratılmıştır ve ancak bu yaratım kapasitesinin kendisine "bahşedildiği" insan sözüyle bilinir. ${ }^{58} \mathrm{Bu}$ nedenle nesnelerin dilinden insanın diline yapılan "çeviri", sadece dilsizin sesliye değil, adsızın da ada çevirisidir. Yani nesnelerin adı insandan nesneye bahşedilmemiştir, insan da nesne de yaratım uzamının bir parçasıdır fakat insan yaratıma adlandırma kapasitesi ile dahil olduğundan insanın sözü, nesnenin adını dile getirir. ${ }^{59}$

İlk günahı insanın sözünün doğum anı olarak kabul eden Benjamin’e göre, günahla birlikte dildeki içsel büyü addan, dışsal bir büyü olan söze geçer. Böylece iyinin ve kötünün bilgisi sözde "yargı" olarak açığa çıkar. Yargı veren sözün büyüsü, adın büyüsünden farklıdır ama yine de dolaysızlığı ve soyutlama kapasitesi nedeniyle büyülüdür. ${ }^{60}$ İnsan sözünün bildirdiği yargı, tam da insanın söylemi inşa edebilmesine ve inşa ettiği söylemin bir yapı olan nomos'u açığa çıkarmasına işaret eder. Dolayısıyla vardığımız nokta artık, ad, söylem ve yasa ilişkisinin çözümlenip yeniden düzenlenmesine imkân sağlamaktadır.

Ad, dilin yaratıcı karakteridir; diğer varlıklardan farklı olarak adlandırma kapasitesine sahip olan insanın sözünde nesnelerin adları sunulur (presentation); yeniden-sunum (re-presentation) ise söz ve söylemde açığa çıkar. Söylem, insan sözünde nesnelerin adlarının birbirleriyle ilgisinin

55 Walter Benjamin, "Genel Olarak Dil ve İnsan Dili Üzerine”, Walter Benjamin Kitabı: Seçme Yazılar, Çev. Tunç Tayanç, İstanbul: Dipnot Yayınları, 2018, s. 133.

56 Benjamin, "Genel Olarak Dil”, s. 134-135.

57 A.g.e., s. 136.

58 A.g.e., s. 142.

59 A.g.e., s. 143.

60 A.g.e., s. 145. 
kurulduğu düzlemdir ve yargı bildirir. Dolayısıyla Platon'un iddia ettiği gibi ad'ın yasa ile doğrudan (zorunlu) bir ilgisi yoktur; fakat adın iyiliği veya kötülüğü yani adın söylemde yargı bildirmesi yasa bahsini açar. Nomos'un kurucusu ve koruyucusuna duyulan gereksinim (Platon'da ad/yasa-koyucular, Aristoteles'te dili akıl yürütme yetisi gelişkin olan efendi) de buradan neşet eder. Platon da Aristoteles de her insanın (köle veya efendi) şeylerin adlarına "kendiliğinden" (doğal değil, bir aksiyom anlamında) sahip olduğunun farkındadır. Dolayısıyla sorun, vardığımız noktadaki kavramlarla söylersek; ad vermede yani sunumda değildir; yeniden-sunumda yani söylem ve söylemin yargı bildiren doğasındadır. Bu noktanın yeniden bir paradoksa dönüşmesini engelleyecek olan ise bize göre ad ile söylem arasındaki aktüel ilişkidir.

Söylem, nesnelerin kendilerinden değil; yaratım ürünü olan adlardan oluşur ve adları bir araya getirip düzenleyen dil de yaratım kapasitesine sahip insan sözünün düzlemidir. Koç’un makalesi ile bir arada düşünürsek, ad ve söylemi yasaya bağlayarak, yasanın doğallığını veya uzlaşımsallığını iddia etmek ancak ve ancak dilde nesnelerin bizatihi kendilerinin açığa çıktığını savunmakla mümkündür. Platon ve Aristoteles’in tartışmayı doğalcılık ve uzlaşımsalcılığın ötesine taşımamasının nedeni, adı, nesnelerin ampirik düzlemdeki tezahürlerine içkin kılmalarıdır. $\mathrm{Bu}$ nedenle adı, yaratım edimi; dili, bir yaratım kapasitesine sahip insanın yaratım düzlemi olarak düşünmek, dilde düzenlenen adların nesneler dünyasını dönüştürme ve düzenleme kapasitesine sahip olduğunu açığa çıkarır.

Daha da önemlisi, dil tasarımının kaçınılmaz bir şekilde insan tasarımını da etkiliyor oluşudur. Platon ve Aristoteles düşüncesinde dilin doğal olması gibi insanın diğer varolanlar gibi doğal bir varlık olarak tasarlanmasıdır. Böyle bir tasarıda adın, ampirik düzleme bağlanması gibi insan da efendi ve köle gibi ampirik ayrımlara bağlanır. İnsana dair efendi ve köle ayrımı ve ikisi arasındaki ilişkinin doğal olduğunu ve yasalarca sabitlendiğini iddia etmek, ancak nesnelerin ampirik düzlemde birbirlerine dokunduğunu kabul etmekle mümkündür. Fakat yukarıda anlattığımız üzere bu mümkün değildir. Benjamin’in adı, "dilin dili” olarak saptamasının böyle bir okumada karşılığı şudur: Ad ve ad verme, insanın doğal tasarımına eklenen (tinsel) bir fazlalıktır ve bu fazlalık, hem dilin doğallığını ve uzlaşımsallığını hem de insanın köle ve efendi olarak tasarlanmasını sınırlayabilir. Böylece "ad”, "söylem” ve “yasa” ilişkisi Platon ve Aristoteles'te olduğu gibi doğal değil aktüel bir nitelik kazanabilir. Bununla bağlantılı olarak sırasıyla, "dil”, "felsefe" ve "politika" ilişkisinin aktüellik kazanabileceği anlamına gelebilir.

\section{Kaynakça}

Aristoteles. Politika, Çev. Mete Tuncay, İstanbul: Remzi Kitabevi, 1975.

Benjamin, Walter. "Genel Olarak Dil ve İnsan Dili Üzerine”, Walter Benjamin Kitabı: Seçme Yazılar, Çev. Tunç Tayanç, İstanbul: Dipnot Yayınları, 2018.

Benjamin, Walter. The Correspondence of Walter Benjamin: 1910-1940, edited and annotated by Gerschom Scholem and Theodor Adorno, translated by Manfred R. Jacobson and Evelyn Jacobson, London, The University of Chicago Press, 1994.

Benjamin, Walter. The Origin of German Tragic Drama, trans. by John Osborne, London: Verso, 2003. 
Canlı, Emine. "Politik Praksis İmkanı Olarak Walter Benjamin’in Tarih Kavramı Üzerine Bir İnceleme", İstanbul Üniversitesi Sosyal Bilimler Enstitüsü, İstanbul, 2018, Yayınlanmamış Doktora Tezi.

Gören, Erman. Kratylos’a Yorumlar: Physis-Nomos Karşıtlı̆̆ı Bă̆lamında Filolojik ve Yorumbilgisel Bir İnceleme, c. 2, İstanbul: Dergâh Yayınları, 2016.

Koç, Yalçın. "Mekân ve Nesne”, Felsefe Arkivi, İstanbul: Edebiyat Fakültesi Basımevi, Sayı: 29, 1994,13-20.

Lindroos, Kia. Now-time Image-space: Temporalization of Politics in Walter Benjamin's Philosophy of History and Art, Finland, SoPhi AcÂdemic Press, 1998.

Platon, Kratylos: Giriş, Metin, Çeviri ve Dizinler, Çev. Erman Gören, İstanbul: Dergâh Yayınları, c. 1, 2016.

Platon. "Menon", Diyaloglar,İstanbul: Remzi Kitabevi, 1996.

Rancière, Jacques. Tarihin Adları: Bilgi Peotikası Alanında Bir Deneme, Çev. Cemal Yardımcı, İstanbul: Metis Yayınları, Şubat 2001.

Rancière, Jacques. Uyuşmazlık: Politika ve Felsefe, Çev. Hakkı Hünler, İzmir: Ara-lık Yayınları, 2005.

Rush, Fred. "Sunuş", Walter Benjamin Alman Romantizminde Sanat Eleştirisi Kavramı, Çev. Elçin Gen, İstanbul: İletişim Yayınları, 2013, 27-59.

Sartre, Jean-Paul. Varlık ve Hiçlik: Fenomenolojik Ontoloji Denemesi, Çev. Turhan Ilgaz, Gaye Çankaya Eksen, İstanbul: İthaki Yayınları, 2009.

Osborne, Peter. Charles Matthew, "Walter Benjamin”, https://plato.stanford.edu/entries/benjamin/ (Çevrimiçi erişim tarihi: 05.03.2019) 